\title{
Az orvosi hálapénz megoldásának történelmi kulcsa
}

\author{
Balázs Péter dr. \\ Semmelweis Egyetem, Általános Orvostudományi Kar, Népegészségtani Intézet, Budapest
}

\begin{abstract}
Nincs a világnak olyan fejlett országa, amelynek egészségügyi szolgáltatórendszere zavartalanul múködne. Az ok univerzális, ugyanis kivétel nélkül a szolgáltatások köz- és magánfinanszírozásának konfliktusára vezethető vissza. Ennek felszíni jelenségei igen sokoldalúak lehetnek: Magyarországon a hálapénzrendszerben összegződnek, amelynek eredeti mintája három évszázaddal ezelőtt keletkezett. Ha nem a valós okot kezeljük, minden kezdeményezésünk eredménytelenül fog végződni. Németország és az Egyesült Királyság mintaértékú rendszerei azért múködnek hálapénz nélkül, mert egyensúlyi megoldást találtak a köz- és a magánfinanszírozás együttélésére. Magyarországon sincs más kiút az egyre értelmetlenebb pótcselekvések helyett, de egy új és hosszú távú társadalmi közmegegyezés csak tudományosan megalapozott bizonyítékokra építhető.
\end{abstract}

Orv Hetil. 2019; 160(2): 50-56.

Kulcsszavak: hálapénz, köz- és magánfinanszírozás, új társadalmi közmegegyezés

\section{The historic master key to get rid of medical doctors' informal payment}

There is no nation in the developed world without dysfunctions of its health care system. The cause behind is universal since it goes back to the historic conflict of private and public financing of services. Phenomena on the surface are multi-faceted, in Hungary they are concentrated in the doctors' informal payment the original pattern of which was emerging three centuries ago. While neglecting our series of mismanagement, all our new initiatives will disable any real solution. The world's best health system models in Germany and the United Kingdom function without informal payment. Their substantial models compromise private and public financing. Instead of questionable ideas, Hungary needs to find its own relevant solution based on a new deal with the society but it must have a firm base of scientific evidences.

Keywords: informal payment, public/private financing, new deal with the society

Balázs P. [The historic master key to get rid of medical doctors' informal payment]. Orv Hetil. 2019; 160(2): 50-56.

(Beérkezett: 2018. július 4.; elfogadva: 2018. július 31.)

\section{Rövidítések}

GNRS = (generale normativum in re sanitatis) egészségügyi fószabályzat; MABI = Magánalkalmazottak Biztosító Intézete; MÁV = Magyar Államvasutak; MOK = Magyar Orvosi Kamara; NDK = Német Demokratikus Köztársaság; NHS = (National Health Service) Nemzeti Egészségügyi Szolgálat; tb = társadalombiztosítás

A magyar hálapénzrendszer azért jöhetett létre, mert az egészségügyi közfinanszírozás folyamatosan nyomott áron díjazta és díjazza ma is az orvosi munkát, és soha nem jelölte ki világosan a határvonalat a köz- és a ma- gánfinanszírozás között. Kétségtelen, hogy a hazai hálapénzkutatás „elsősorban a lakossági motivációkra, kifizetésekre és azok megoszlására" irányult, és kevésbé foglalkozott az orvostársadalom szempontjaival [1]. Ennél is nagyobb azonban a hiány kellő mélységű történelmi elemzésekből, ám mulasztásainkat követően csak egy ilyen kellő mélységű és tényekre alapozott elemzés az egyedüli biztosíték arra, hogy pótcselekvések (fizetésemelés, szabályozott betegutak, rezidensi fogadalom stb.) helyett végre kijelöljük a helyes megoldás irányát. Reménytelen azt hinni, hogy a mélyben forrongó és a hálapénzt túlnyomásos szelepként múködtető társadalmi feszültségek megoldhatók volnának hasonló nagyságren- 
dű konfliktusok vállalása nélkül. Ezt az utat végigjárni azonban csak erős társadalmi támogatottsággal lehetséges, amelyhez nemcsak bátorság és akarat, hanem szilárd tudományos alapokra épített meggyőződés is szükséges.

\section{Mi az orvosi munka ára?}

Erre az alapkérdésre az a helyes válasz, hogy az egészségnek, illetve a helyreállításához kifejtett szolgáltatásnak nincs és soha nem is volt gazdaságilag pontosan meghatározható értéke. Ráadásul az orvoslás az ókortól kezdve két külön rendszerben, szakrális és világi módon múködött.

A szakrális változatban a gyógyult betegek nem az orvos-papokat díjazták, hanem a hálájukat fejezték ki az őket megsegítő természetfeletti hatalomnak (istenségnek). A hála mértéke kinek-kinek a saját tehetősségéhez igazodott, amelyet kezdetben naturáliákban, később vagyontárgyakban, majd hálapénzben fejeztek ki. A bevételek a gyógykultuszok hírnevének terjesztését és sajátos tárgyi eszközeinek fejlesztését szolgálták.

A profán orvoslásban, kétkezi mesteremberi munka lévén, a díjazás értékelméletileg a reálgazdaságra támaszkodhatott. Hammurápi babiloni király (Kr. e. 17281686) 282 paragrafusból álló törvénykönyvében kilenc szakasz (215-223. \$) foglalkozott a sebészi orvoslással és annak díjtételeivel [2]. Mivel a mesterembert, ha már megbízták, kötelező volt megfizetni, a törvénykönyv a fizetésképtelenséget nem tárgyalta.

Több mint ezer évvel később Hippokratész (Kr. e. 460-375) iskolája a szakrális mintát átemelte a világi orvoslásba, így a betegek tehetősségük szerint fizettek a szolgáltatásért. Ezt a rugalmas tarifarendszert a hippokratészi medicinát múvelő középkori szerzetesrendek és a papok is elfogadták. Ennek az üzletelésnek IX. Gergely pápa (1227-1241) vetett véget, mivel kitiltotta az egyházat, különösen a „véres” orvoslásból [3]. Ettől kezdve a szakma iparosai (sebészek, bábák, fürdősök) - római jogi mintára - vállalkozási díjat kaptak, az egyetemi diplomás orvosok (akik felszentelt papok nem lehettek) pedig munkadíjat. Közkeletű tévedés szerint ez utóbbi nem tiszteletdíj (honorarium) volt, azzal ugyanis megbízás (mandatum) keretében csak a kiemelten magas színvonalú szellemi munka végzőit tisztelték meg, például jogi képviselet ellenében. Jellemző, hogy a latin nyelvü magyar Generale normatioum in re sanitatis (GNRS, 1770) - lényegében a Habsburg birodalmi egészségügyi föszabályzat tükörfordítása - a honorariumot egyetlenegy helyen sem említi. Ellenben palmarium (sikerdíj), merces medendi (kezelési díj), illetve praemium (fizetség) olvasható a megfelelő fejezetben [4].

Az orvosi munkadíjak mértékében a középkori, sőt a kora újkori Európa is II. Frigyes német-római császár (1220-1250) melfi konstitúcióját (1231) követte [5]. A törvény a szolgáltatáshoz szükséges időtartamot használta alapegységként, és a vizitdíj fogalmába sürítette. Összege az orvos és a beteg lakása közötti távolsághoz, illetve a napszakhoz igazodott. Ötszáz évvel később ugyanez az alapelv érvényesült Poroszországban, ahol I. Frigyes Vilmos (1713-1740) 1725-ben adta ki „Porosz királyi és brandenburgi választófejedelmi általános és szigorított orvoslási ediktum és rendtartás" címú rendeletét [6]. A 6. $\$$ indoklása szerint „annak érdekében, hogy minden orvos, sebészmester és patikus előzetesen tudja, hogy az általa végzett sokféle munkáért és gondosságért milyen összeget kérhet és fizettethet ki magának, másfelől a betegek se panaszkodhassanak a túlzott megterhelésre", a 32. számú mellékletben tételes díjtáblázat (taxa) állt rendelkezésre. Ennek értelmében a díjak „nem kötik meg az előkelő és vagyonos emberek kezét, hogy az orvosok és sebészmesterek szorgosságát, gondoskodását és hűséges munkáját további hozzájárulással és nagylelkûséggel is elismerjék; a taxa irányárai elsősorban azoknak szólnak, akik biztosított megélhetésük mellett olyan helyzetben vannak, hogy illendő módon megtéríthetik az orvos és a sebészmester fáradozását". Szabad egyezkedés tárgyát egyedül a szifilisz kezelése képezte.

A Habsburg egészségügyi jogalkotás, jóllehet a porosz mintát zsinórmértékként kezelte, mereven elzárkózott mindenféle díjtáblázattól. Ennek ellenére magyar részről a XVIII. században két legfelső szintű kísérlet is történt a tarifák bevezetésére. Először a helytartótanács egészségügyi bizottsága 1755-ben úgy döntött, hogy az 1745-ben kihirdetett Torkos-taxa [7] sebészi díjainak mintájára „az elkérhető díjakról és fizetségekről az orvosok részére is teljesen azonos módon meghatározott normát és szabályzatot ír elő, egyelőre azonban a dolgok körülményeit minden oldalról mérlegelve a bizottság abban állapodott meg, hogy az egyszerüség kedvéért, a számos előre várható nehézség miatt ezzel jelenleg nem kíván foglalkozni” [8]. A második, határozottabb állásfoglalást az 1790-91. évi országgyúlés által megbízott közpolitikai bizottság hozta, 1793-ban. Az új egészségügyi törvényjavaslat mellé egy rendelettervezetet is öszszeállítottak, az 1725. évi porosz táblázat díjainak tükörfordításával. A bizottság szerint „a taxát úgy kell értelmezni, mint amely kötelező díjakat tartalmaz, és ezeknél kevesebbet nem lehet fizetni” [9]. Tehát a túlfizetéssel ellentétben hazai gondjainkat elsősorban az orvosi munka mértéktelen leértékelése okozta. Sajnos a magyar országgyúlés a tervezetet soha nem vette napirendjére. Nyolcvan évvel később azonban újra felmerült a kérdés a közegészségügyről szóló 1876. évi XIV. törvénycikk (tc.) előkészítése során. A hatályos szöveg 48. $\$$-a szerint „a magánorvoslás díjazása kölcsönös megegyezéstől függ, hol ilyen létre nem jött, peres esetekben szakértők meghallgatásával a bíróság határozza meg a díjat, amelynek legkisebb mértéke az egész országra kihatólag, azonban tekintettel a városok és községek különböző viszonyaira, fokozatosan a belügyminiszter által állapíttatik meg" [10].

A szocialista egészségügy (1948-1989) hosszú szünete után a legújabb állásfoglalást a Magyar Orvosi Kamara (MOK) 1998. március 21 -én véglegesített etikai statútu- 
mának 138. szakasza tartalmazta. „A vállalkozás keretében, illetve magángyakorlatot folytató orvos joga, hogy munkája díját maga határozza meg - és megfelelő árlista hiányában figyelembe kell vennie szolgáltatásának értékét, saját kiadásait, kvalifikációját és amennyire lehetséges, a beteg anyagi körülményeit” [11]. Nyilvánvaló változás, hogy kölcsönös megegyezés helyett újabban az orvos döntött. Jelenlegi állás szerint a magánpiaci orvosi munkadíjak meghatározásának hazai története 2005. december 3-án zárult, amikor a MOK országos küldöttközgyúlése a fenti és a hozzá csatlakozó két további szakaszt (138-140.) törölte a szabályzatból [12]. Következésképpen jelenleg semmilyen támpontunk nincs arra nézve, hogy a magánfinanszírozásban mihez igazodjék az orvos díjazása.

\section{Szociális szempontok a közfinanszírozásban}

Kezdetben a szociális dimenzió - szegénység vagy nincstelenség okán - mint az orvos egyéni jótékonysága jelentkezett a díjazásban. Szociális indíttatású azonban - a teljesség kedvéért - a túlfizetés is, amennyiben a beteg saját gazdagságának látványos (esetleg megalázó) érzékeltetésére, a szokásosnál többet fizetett az orvosnak.

Nagyobb közösségekben, majd később társadalmi szinten a jótékonyság 1) magánfelek között, 2) a közösség és az orvos, illetve 3 ) az egész társadalom és az orvos viszonylatában jelenhetett meg. Magánalapon az orvos lemondhat a díjáról vagy annak egy részéről a nincstelen vagy a szegény beteg javára. Közösségi szinten az első példát a középkori és kora újkori városok szerződései szolgáltatták. Az orvosnak a közegészségügyi igazgatásban végzett feladatokért időbért (éves fizetés) kötöttek ki, amelybe a városi szegényeknek végzett kötelező ellátást („ingyen rendelés”) is belefoglalták. Ez volt a modern közfinanszírozás őse, mivel a város az orvos fizetését közpénzekből folyósította.

Kezdetben a központi államigazgatás az orvosok szociális érzékenységére hagyatkozott. Ennek világos példája a porosz rendtartás 32. számú melléklete: „szegény emberek esetében, akiknek létfenntartása is kétséges, és tartalékaik sincsenek, a lelkiismeretes orvos emlékezzék a tőle kötelezően elvárható keresztény szeretetre és arra, hogy e tekintetben mi a kötelessége, és az ilyen betegtől se vonja meg tanácsait és segítségét".

Újabb fordulat a felvilágosult abszolutizmusban következett, az egészségért viselt „legfelsőbb” felelősség és cselekvés formájában. Hazai vonatkozásban Mária Terézia (1740-1780) a GNRS preambulumában hirdette meg, hogy „anyai gondoskodásaink közepette... elsőrendű az a törekvésünk, hogy alattvaló népeink egészségét megörizzük..." [13]. Természetesen a döntő kérdés az „anyai gondoskodás” pénzügyi fedezete volt. Először 1752. október 26-án lépett hatályba egy rendelet, amely a vármegyei tisztviselők és szolgák (officiales et servitores) fizetésének mérséklésére intette az illetékeseket. Ez eleve semmi jót nem ígért a rendelet szerint servitoresként kö- telezően alkalmazandó orvosoknak (és sebészmestereknek). A közszolga orvos „állandó lakása, amennyiben lehetséges, a vármegye területén legyen, és a hozzá forduló adófizető köznépnek ingyenesen (gratis) írja fel a recepteket, ahol pedig nincs patika, saját múködtetésében az orvosságokat elviselhető áron forgalmazza” [14].

Az országos és nyomott szintû hazai közfinanszírozás nyitánya után három évvel a jogalkotás a mai hálapénzrendszer ősbúnét is elkövette, amennyiben egymásra csúsztatta a szolgáltatások magán- és közfinanszírozását. A tengerészeti közegészségügyről szóló, 1755. évi úgynevezett trieszti rendelet (amely Fiumére is vonatkozott) 16. fejezetének 8. szakaszában található a mai olvasónak nagyon ismerős következő mondat: „A közegészségügyi orvos és segédje, betegség esetén fizetség nélkül kötelesek ellátni a közegészségügyi magisztrátus tagjait, valamint a közegészségügyi hivatalnokokat és az ellenőröket is. Ugyanakkor nincs megtiltva a fizetség elfogadása, ha annak felajánlása a betegség alatt vagy utána, önként és tisztán nagylelküségből történt” [15].

Mai hálapénzrendszerünk miatt érdemes a fenti mondatot alaposan átgondolni. Adva van egy közfinanszírozott, térítésmentes ellátás, amely a szerény jövedelmú közegészségügyi ellenőrtől kezdve a legtehetősebb magisztrátusi tanácsosig mindenkire kiterjed, de a kedvezményezettek jogszabályilag biztosított módon „önként és tisztán nagylelküségből” (freiwillig und aus blosser Generosität) az orvost még külön is díjazhatják. Alsó szinten nyilvánvalóan örömmel fogadták a kedvezményt, hiszen olyan orvosi ellátást élvezhettek, amelyet különben képtelenek lettek volna megfizetni. Felső és különösen legfelső szinten viszont senki nem szorult rá az ingyenességre, de ezek a tisztviselők háromféle módon viselkedhettek: 1) gazdagságuk érzékeltetésére úgy fizettek, mintha nem lettek volna kedvezményezettek, 2) az orvos szokásos díjához képest mérsékeltebb összeget adtak, vagy 3) semmit nem fizettek, így elfogadták az ingyenességet. A középréteg, ha vállalta a társadalmi presztízsveszteséget, az alsó jövedelmi szinthez igazodhatott, ha nem, akkor erején felül fizetett a tehetősség látszata érdekében. Keletkezése pillanatában láthatjuk tehát a hálapénzes rendszer alapmodelljét, amely kíméletlen következetességgel érvényesült a XVIII. századtól mind a mai napig, ha a hibát hibára halmozó közfinanszírozás ezt lehetővé tette.

\section{Mintaértékű rendszerek - hálapénz nélkül}

Az egészségügyi szolgáltatásokban természetes jelenség a köz- és magánfinanszírozás párhuzamossága. Ezt az állapotot csak a szovjet típusú XX. századi szocialista egészségügy utasította vissza a szolgáltató és finanszírozó rendszer totális államosításával.

Európa szervesen fejlődött piacgazdasági részében két mintaértékű rendszer alakult ki, az egyik Németországban, a másik az Egyesült Királyságban. Mindkettő leírható olyan terjedelmes és bonyolult módon, hogy ponto- 
san a lényeg vész el, vagyis az egészségügyi piacgazdaság köz- és magánfinanszírozásának szabályozott párhuzamossága. Ezek a rendszerek sem hibátlanok, de a jelen esetben arra kell szorítkozni, hogy milyen módon választják el egymástól azokat a betegeket, akik egyfelől szociális támogatásra szorulnak az ellátásban, másfelől hogyan helyezik ki azokat a magánpiacra, akik nem jogosultak a társadalom ilyen szolidaritására. Az utóbbi betegeknek csupán az a „büntetésük”, hogy tehetősségük miatt piaci áron fizetik meg az orvosok mindenkori munkadíját. Megelőlegezve az alábbi gondolatokat, a legrosszabb emlékű szociáldemagógia ezt a társadalom kettészakításának nevezi, a „szegények és gazdagok” szembeállításával.

Németország 1883-tól, vagyis a szociális betegbiztosítás hatályba lépésétől „ketté van szakítva” kötelező és magánágazatra. A hatályos jogszabály [16] éves/havi munkajövedelem határhoz köti a jogosultságot. Ennek felső határa a bérből és fizetésből élők esetében 2018ban 4950,00 euró/hónap [17]. A tőkejövedelemmel rendelkezők a főszabály szerint nem jogosultak szociális biztosításra. A kötelező biztosítottak egyébként többletszolgáltatásokra (például orvosválasztás a kórházban, elhelyezés 2 ágyas szobákban, fogorvosi kezelés) kiegészítő biztosítást köthetnek. A kötelező biztosítottak pontosan tudják, hogy mi illeti meg őket, és azt is tudják, hogy nem másodosztályú kezelésben részesülnek. A tehetősebb társadalmi réteg a magánbiztosításba tartozik. Itt a kezelés költségesebb, de elsősorban nem a tárgyi erőforrások, hanem az orvosi munkadíjak következtében. Negyven év szocializmus után az egykori Német Demokratikus Köztársaság (NDK) különösebb megrázkódtatás nélkül tért vissza az 1883-ban létrehozott eredeti modellhez. Ezt nagyon is szem elött kell tartanunk, hogy emlékezzünk arra, milyen lehetőséget mulasztottunk el az 1989-es rendszerváltozás kapcsán.

Az Egyesült Királyság 1911-ben vette át a német modellt, de a keresók jogán az önálló jövedelemmel nem rendelkező családtagoknak nem adott biztosítási jogosultságot. Sok más ok mellett, a többi között ezért is váltottak át 1948. július 5-tól a National Health Service (NHS) rendszerére. Ekkor a természetbeni egészségügyi ellátás közfinanszírozásának forrását áthelyezték az adórendszerbe, vagyis 1948 óta ezek fedezetét az általános adóbevételek adják. Egészségbiztosítási jogviszony helyett tehát állampolgári jogon jár az ellátás Angliában, Walesben, Skóciában, illetve Észak-Írországban. Az NHS éles határt húz a magánpiaccal szemben, ahol közvetlenül zsebből vagy üzleti biztosítással kell fizetni. Különösen ügyelnek erre a fekvőbeteg-ellátásban, ha maga az NHS köt szerződést a magánszolgáltatókkal. Ilyen esetben a köz- és magánfinanszírozott szolgáltatást térben és időben is kötelező elkülöníteni. Továbbá a beteg nem bonthatja meg az NHS szolgáltatási csomagját (például kataraktaműtét esetén a beavatkozás egészének része a standard unifokális lencse, amely helyett magánala- pon multifokális lencse nem kérhető) [18]. A világos és tiszta szabályoknak köszönhetóen az Egyesült Királyság rendszere mentes maradt a magyar hálapénzes gyakorlathoz hasonló üzleteléstől.

Szociális szempontból különben meglepő eredmény, hogy két teljesen különbözó útvonalon ugyan, Németországban [19] és az Egyesült Királyságban [20] is a teljes népesség 11\%-a (gyakorlatilag a felső jövedelmi tized) rendelkezik magánbiztosítással.

\section{Hibáink sorozata 1891-től}

Minden közfinanszírozási modellünket külföldről másoltuk, majd következetesen figyelmen kívül hagytuk, hogy az eredeti rendszereket nem lehet tetszés szerint manipulálni. Következetesen elkövettük a közös bűnt, hogy gátlástalanul alacsony szinten számoltunk az orvosi munkadíjakkal, és ellenségesen viselkedtünk a magánfinanszírozással szemben. Az első korszakot a munkásbiztosítás [21] fémjelezte, a másodikat 1927-től a „betegségi és baleseti kötelező biztosítás” [22], a harmadikat a szocialista társadalombiztosítás (tb) 1975. évi törvénye [23], a negyediket pedig ma is „élvezzük” mint az 1989es rendszerváltozás utáni átalakítás eredményét [24].

Mind a négy korszak első számú kárvallottja a magánellátás és a magánfinanszírozás, ami eredeti magyar fejlemény, ugyanis egyáltalán nem következik sem a német, sem az angol modellból. Magyarországon az orvosi magánpiacot az első két korszak következetesen sanyargatta, a szocialista egészségügy üldözte, az 1989-es rendszerváltozás pedig gazdasági karanténba zárta.

\section{Munkásbiztositási korszak (1891-1927)}

Az 1891-es munkásbiztosítás (mintegy az 1755. évi trieszti rendelet szellemi örököseként) olyanoknak is kedvezett (iparban, bányászatban, szállítmányozásban, postaszolgálatban), akik erre nem voltak rászorulva. Négy forint/nap, illetve 1200 forint/év volt a jogosultság ha-

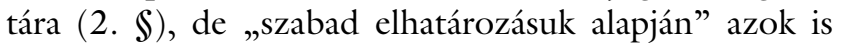
csatlakozhattak, akik „1200 forintnál magasabb évi vagy 4 forintnál magasabb napi fizetést vagy bért élveznek" (4. $\$ / b)$. Ennek alapján a középosztály alsó és középső része a munkásbiztosításba menekült, és egyáltalán nem gondolt arra, hogy „önként és tisztán nagylelkűségből” külön is díjazza az orvost. Olyan mértékben nyilvánvaló volt a menekülés, hogy az Országos Orvosszövetség már 1899-ben szigorú felső határt követelt, vidéken 1200 korona, a fóvárosban 2400 korona/év értékben (2 korona $=1$ forint) [25]. Jogszabályilag ez először 1907-ben (XIX. tc.) jelent meg a balesetbiztosításban. Összegezve a fentiek tanulságát, ha nincs egyértelmű kizárásos jövedelemhatár, csak a társadalmi felsőbbrendûség tudata tartja vissza az embereket attól, hogy beálljanak az „ingyenességet” élvezők táborába. 


\section{Betegségi és baleseti kötelezö biztositás} (1927-1948)

A fizikai munkásokat ez a biztosítás is bérhatár nélkül vette fel a rendszerbe. Tanulva azonban az előzményekből, a 3 . $\$$ szerint „a munkavállalók közül a tisztviselők, a mûvezetők, a kereskedősegédek és általában a hasonló állásban levő, rendszerint havi vagy évi fizetéssel alkalmazottak" csak abban az esetben voltak kötelezettek, ha javadalmazásuk évi 3600 pengő, illetve havi 300 pengő összeghatár alatt maradt. A „kiskaput” azonban ez a szabályozás is nyitva hagyta. „Egy jól jövedelmező bérház tulajdonosa, krónikus bajaira való tekintettel formailag képviseletet vállalt az egyik nagy biztosítónál, ahol talán még a szivarravalóját sem kereste meg, és ilyen címen a legolcsóbb díjtétel alapján jogosult tagja volt a MABInak" [26] (MABI = Magánalkalmazottak Biztosító Intézete). A magánbetegek számának csökkenése miatt a közalkalmazotti állással is rendelkező orvosok napjaink számára is tanulságos „költségmegtakarítási” megoldást alkalmaztak, és magánbetegeiket berendelték a közkórházakba. Korabeli megállapítás szerint az ilyen orvos „rendeléskor a kórház anyagait használja, adót nem fizet, és így a kórházon kívüli magánorvosoknak tisztességtelen konkurenciát csinál” [27]. A legális magánbetegek természetesen nem hálapénzt adtak, de az orvosok a rendelő üzemeltetési költségeit áthárították a közfinanszírozásra. Zárójelbe téve, egyszer érdemes volna azon is elgondolkodni, hogy jelenleg ezek a költségek mennyiben járulnak hozzá a kórházak eladósodásához.

\section{A szocialista tb közfinanszírozása (1948-1989)}

Egyetlen korszakon belül a német és az angol alapmintát is hiteltelenné tettük. Először a német rendszer került sorra. Tőkejövedelemmel eleve nem kellett foglalkozni, hiszen a szocializmusban ilyesmi nem létezhetett, a munkajövedelmek alacsony szintjét pedig a javak közvetlen központi elosztása magyarázta (más kérdés, hogy ebból az egyes társadalmi rétegek milyen mértékben részesedtek). A biztosítóintézetek 1948-as államosítása után 1950-ben a 139. számú minisztertanácsi rendelet betegség és baleset tekintetében a biztosítottak ellátását állami feladattá tette. Egyidejűleg kérlelhetetlen és indulatos üldözés folyt a magánpraxis ellen.

Magánbetegek még az 1960-as évek elejéig voltak a rendszerben, a mezőgazdaság szocialista átszervezéséig. Ekkor a mindenkire kiterjedő kötelező szocialista tb „éretté vált" arra, hogy az angol NHS típusú rendszert is hiteltelenné tegye. Ez a lépés csak az 1975. évi II. törvénnyel következett be, amely kimondta a betegellátás állampolgári jogosultságát. Összefoglalva, a szocialista tb az orvosi magánpraxis és a magánfinanszírozás felszámolásával indította útjára azt a kvázi magángazdaságot, amely ma is meghatározó alapja a hálapénzes üzletelésnek.

\section{Rendszerváltozás - 1989}

A korszak emblematikus alkotása a fentiekben már idézett, 1991-es „Cselekvési program egészségügyi rendszerünk megújítására”, amelynek a „Magyar egészségügy finanszírozási rendszerének alapkoncepciója" is a részét képezte. A program V. fejezetének (társadalombiztosítás - kötelező betegbiztosítás) 2 . bekezdése (betegbiztosítás) szerint a „kötelező általános betegbiztosítás a munkabérek, munkával szerzett jövedelmek meghatározott arányában gyưjti össze a lakosságtól és a munkaadóktól az egészségügyi szolgáltatások fedezetét". Ez alapjában véve helyes megállapítás, de visszhangozza az 1891. évi munkásbiztosítás hibáját, amennyiben a jövedelemhatárt meg sem említi, sőt egyenesen mindenki számára kötelezővé tette a betegbiztosítást, ráadásul a kialakuló piacgazdaság tőkejövedelmeit is figyelmen kívül hagyta. Ennek kapcsán nem érdektelen emlékeztetni arra, hogy a volt NDK-ban a Cselekvési programmal egy időben zajlott az eredeti német modellhez való visszatérés, tehát a többi volt szocialista ország is példát meríthetett volna a szocialista tb hagyatékával való teljes leszámoláshoz. Ilyen megoldás fel sem merült, de a program jól érzékelte, hogy valamilyen módon mégis kezelni kellene a Magyarországon is jelen lévő magánkeresletet. Erről szól a 7 . bekezdés, amely „lefölözés" céljából a német rendszerben teljesen más körülmények között múködő kiegészítő biztosítást hívta volna segítségül. Németországban a kiegészítő modell a kötelező biztosítottak magasabb jövedelmü részének szól, és nem a társadalom felső $11 \%$-ának, vagyis a magánbiztosítással rendelkező legnagyobb munka- és tőkejövedelmű rétegnek. Mellőzve a napjainkig húzódó események részletezését, időközben a tőkejövedelmek bevonása a mindenkire nézve kötelező társadalombiztosításba inkább reménytelen kísérlet volt, és a felszínen hálapénzrobbanásként terjedő jelenséget inkább ösztönözte, mintsem akadályozta.

\section{Mit kell átgondolni bármilyen újabb lépés előtt?}

A Cselekvési program 1991-ben úgy vélte, hogy az "alapvető egészségügyi szolgáltatások körét meghaladó” elvárások között „luxusigények” fordulhatnak elő, továbbá olyanok, amelyek kielégítését „a technikai, gazdasági, szociális fejlettségi szint nem teszi lehetővé”. Az előbbiek eléggé egyértelmúen a komfort-, illetve hotelszolgáltatásokra irányultak, az utóbbiak szakmai természetűek.

Kétségtelen, hogy a szakmai szolgáltatásokat csak a leggazdagabb országok képesek ugyanolyan színvonalon biztosítani a közfinanszírozásban, mint a magánfinanszírozásban. Következésképpen a minőség és a rendelkezésre álló mennyiség ellentétbe kerülhet egymással. A feloldást a világban mindenhol a várólisták jelzik. Ezeket a 
hazai közvélemény és az egészségpolitika is elfogadta, és észszerū határok között senki nem kifogásolja.

$\mathrm{Az}$ úgymond luxusigények kapcsán bonyolultabb a helyzet. Kielégítésük nem szerves része a szakmai ellátásnak. A járó betegek a nap 24 órájában a komfortot saját otthonukban élvezhetik. Kórházban viszont érthetó okokból senki nem akar az otthoni környezeténél alacsonyabb komfortfokozatba kerülni. Ez mindenkinek más színvonalat jelent, de a magasabb komfortfokozat csak a legrosszabb emlékű szociáldemagógiában kapcsolódik össze a „szegényekre és gazdagokra” kettészakadó egészségüggyel. Társadalmi egyetértést kell tehát teremteni ennek a hazugságnak a kizárására. Jelenleg Magyarországon senki nem ütközik meg azon, hogy a MÁV-nál I. és II. osztályra szóló jegyet lehet vásárolni. Az pedig teljesen nyilvánvaló, hogy a szakmai szolgáltatásban (szállítás $\mathrm{A}$ városból $\mathrm{B}$ városba) teljes az egyenlőség. $\mathrm{Az}$ egészségügyben is ezt a szemléletet kell hitelessé tenni.

\section{Hol lesz a megoldás?}

Érzékelve a posztszocialista tb-modell teljes kudarcát, az utóbbi években megtettük az első lépéseket az NHS típusú közfinanszírozás irányába. Az Alaptörvény (2011. április 25.) már nem tartalmazza az 1949. évi és a rendszerváltozás kapcsán 1989-ben módosított alkotmányban foglalt állampolgári jogot, miszerint „az élet, a testi épség és az egészség védelmét" a társadalombiztosítás biztosítja $(58 . \$, 2$. bek.) [28]. Ettől függetlenül a hatályos 1997. évi LXXXIII. törvény [29] a „kötelező egészségbiztosítás ellátásairól" szól, azonban a munkáltatói járulék befizetése már adóként történik, és a „pénztár” szót az egészségügyi szolgáltatások közfinanszírozását bonyolító Nemzeti Egészségbiztosítási Alapkezelő neve sem tartalmazza. A további részletek mellőzésével az utolsó lépést akkor tennénk meg az NHS-rendszer felé, ha a jelenlegi munkavállalói egészségbiztosítási járulék természetbeni szolgáltatásokat fedezô részét is áthelyeznénk az adórendszerbe. Ez nem jelentene visszatérést az 1975. évi II. törvénnyel bevezetett állampolgári jogú ellátáshoz, ugyanis mindezt olyan piacgazdaságban tennénk, amely nem üldözi a magánpraxist, és számításba veszi, hogy a munkajövedelmekben jelentős különbségek alakultak ki, nem beszélve a hatalmas tőkejövedelmekről.

A kétféle megoldás - mivel ezek között választhatunk - modellezése és menetrendje részletkérdés, de ennek kapcsán a közfinanszírozás negyedik évszázadában végre határozott döntést kellene hozni. Melyik a valójában járható út egy hálapénztől mentes egészségügyi ellátás modelljéhez? Netán forduljunk vissza az eddig megtett tévútról a német modellhez, és legyen a fogyasztóknak (betegeknek) egy jól meghatározott köre, amely nem jogosult a társadalombiztosításra, és csak a magánpiacon vásárolhat szolgáltatásokat? Vagy váltsunk át az adóalapú közfinanszírozásra, és szorgalmazzuk a magánbiztosítók múködését? Egyik átalakítás sem fog múködni súlyos tár- sadalmi konfliktusok nélkül, ezeket azonban mégis vállalni kell, hogy több évszázados tévedéseinket belátva, a hálapénzrendszert végre valóban készek legyünk felszámolni.

Anyagi támogatás: A közlemény megírása, illetve a kapcsolódó kutatómunka anyagi támogatásban nem részesült.

A szerző a cikk végleges változatát elolvasta és jóváhagyta.

Érdekeltségek: A szerzőnek nincsenek érdekeltségei.

\section{Irodalom}

[1] Torzsa P, Csatlós D, Eőry A, et al. Opinions of Hungarian family physicians and residents on vocation and informal payment. [Hivatással és hálapénzzel kapcsolatos vélekedések a magyarországi családorvosok és családorvos rezidensek körében.] Orv Hetil. 2016; 157: 1438-1444. [Hungarian]

[2] Dávid A. Code of Hammurabi. [Hammurabi törvénykönyve.] Eötvös Loránd Tudományegyetem, sokszorosított egyetemi jegyzet, Budapest, 1963. [Hungarian]

[3] Linzbauer XF. Decrets of pontifex Gregorius IX, book 3, title 50, chapter 9. Collection of Hungary's Historic Public Health Legislation. [Decretales pontifici Gregorii IX. liber 3, titulus 50, caput 9.] Codex sanitario-medicinalis Hungariae. Budae, 18521861; I-VII/I: 42. [Latin]

[4] Linzbauer XF. General norm of health affairs. [Gererale normativum in re sanitatis.] Codex sanitario-medicinalis Hungariae. Budae, 1852-1861; I-VII/II: 540. [Latin]

[5] Conrad H, von Lieck-Buyken Th, Wagner, W. Constitution of Emperor Friedrich II von Hohenstaufen for his Kingdom of Sicily. [Konstitution Kaiser Friedrich II. von Hohenstaufen für sein Königreich Sizilien.] Böhlau Verlag, Köln, 1973. [German]

[6] General and new sharpened medical edict of Prussian king and prince elector of Brandenburg. [Königliches preussisches und churfürstliches brandenburgisches allgemeines und neugeschärftes Medizinaledict.] Fk. Ober-Collegium Medicum, Berlin, 1725. [German]

[7] Linzbauer XF. Pharmaceutical and surgical fees set by Torkos MD with attached instructions for pharmacists, surgeons, bathers and midwives respectively. [Taxa pharmaceutica et chururgica per M. D. Torkos elaborata; adnexis instructionibus pro: pharmacopoeis, chirurgis et balneatoribus, nec non obstetricibus.] Codex sanitario-medicinalis Hungariae. Budae, 1852-1861; IVII/II: 214-219. [Latin]

[8] Linzbauer XF. Plan of health regulations. [Planum regulationis in re sanitatis.] Codex sanitario-medicinalis Hungariae. Budae, 1852-1861; I-VII/II: 303-307. [Latin]

[9] Minutes of sessions of national committee in public political affaires. [Protocollum consessuum deputationis regnicolaris in public politicis.] Magyar Nemzeti Levéltár Országos Levéltára, Regnicolaris levéltár, Budapest, 1790-1793; N-102, vol. 5: 327349. [Latin]

[10] Hungarian Parliament, Act 1876, XIV, about the public health affairs. [Magyar Országgyúlés, 1876. évi XIV. törvénycikk a közegészségügyről.] Corpus Juris Hungarici (CD-ROM). KJK KERSZÖV, Budapest, 2000. január 1. [Hungarian]

[11] Hungarian Medical Chamber. Code of Ethics. [A Magyar Orvosi Kamara Etikai Kódexe.] MOK, Budapest, 1998. [Hungarian]

[12] Hungarian Medical Chamber. Code of Ethics. [Magyar Orvosi Kamara. Orvosetikai statútum.] MOK, Budapest, 2005. Avail- 
able from: http://www.readbag.com/mok-hu-upload-mokdocument-mok-etikai-kodex [accessed: July 31, 2018]. [Hungarian]

[13] Balázs P. General Code of Health 1770 of Maria Theresa. [Mária Terézia 1770-es egészségügyi alaprendelete.] Magyar Tudománytörténeti Intézet, Budapest-Piliscsaba, 2007; p. 109. [Hungarian]

[14] Linzbauer XF. Statute of county physicians and surgeons. [Constitutio physicorum et chirurgorum comitatensium.] Codex sanitario-medicinalis Hungariae. Budae, 1852-1861; I-VII/II: 297-280. [Latin]

[15] Linzbauer XF. Comprehensive public health regulations and in structions for health officers on the coasts of Inner-Oesterreich. [General-Gesundheits-Ordnung und Instruktionen für die Sanitäts-Beamte in dem Inner-Oesterreichischen Littorali.] Codex sanitario-medicinalis Hungariae. Budae, 1852-1861; I-VII/I: 715. [German]

[16] Code of Social Care, Part V. - Mandatory social health insurance - section 5. Compulsion of insurance. [Sozialgesetzbuch (SGB) Fünftes Buch $(\mathrm{V})$ - Gesetzliche Krankenversicherung - 5. \$. Versicherungspflicht.] Available from: http://www.gesetze-im-internet.de/sgb_5/_5.html [accessed: July 31, 2018]. [German]

[17] Centre of sickness funds, limit 2018 of mandatory health insurance. [Krankenkassenzentrale, Versicherungspflichtgrenze 2018.] Available from: https://www.krankenkassenzentrale.de/wiki/ versicherungspflichtgrenze\# [accessed: July 31, 2018]. [German]

[18] West Midlands Strategic Commissioning Group. Defining the boundaries between NHS and private healthcare. April 2010. Available from: https://www.birmingham.ac.uk/Documents/ college-mds/haps/projects/WMCSU/CommissioningPolicies/WM13-DefiningtheboundariesbetweenNHSandprivatecare.pdf [accessed: July 31, 2018].

[19] Private health insurance. [Private Krankenversicherung.] Available from: https://www.private-krankenversicherungen.net/ [accessed: July 31, 2018]. [German]

[20] Why 'self-paying' for healthcare might not make sense. Available from: https://www.moneysupermarket.com/health-insurance/ self-pay-health-care/ [accessed: July 31, 2018].

[21] Hungarian Parliament, Act 1891, XIV, about the social security of industrial and factory employees in case of diseases. [Magyar Országgyúlés, 1891. évi XIV. törvénycikk az ipari és gyári alkalmazottaknak betegség esetén való segélyezéséről.] Corpus Juris Hungarici (CD-ROM). KJK KERSZÖV, Budapest, 2000. január 1. [Hungarian]
[22] Hungarian Parliament, Act 1927, XXI, about the mandatory health and working place accident insurance. [Magyar Országgyúlés, 1927. évi XXI. törvénycikk a betegségi és baleseti kötelező biztosításról.] Corpus Juris Hungarici (CD-ROM). KJK KERSZÖV, Budapest, 2000. január 1. [Hungarian]

[23] Hungarian Parliament, Act 1975, II, about the social security insurance. [Magyar Országgyúlés, 1975. évi II. törvény a társadalombiztosításról.] Available from: http://net.jogtar.hu/ jogszabaly?docid $=97500002$. TV\&txtreferer $=99600125$.TV $[$ accessed: July 31, 2018]. [Hungarian]

[24] Ministry of Social Welfare. Plan of action for reforming our health affaires. [Népjóléti Minisztérium. Cselekvési program egészségügyi rendszerünk megújítására.] Lege Artis Med. (Melléklet) 1991. augusztus 28. 1-19. [Hungarian]

[25] Lehner K. Income limit of the mandatory health insurance. [A kötelező betegségbiztosítás censusa. Közegészségügyi és orvosrendi kérdések a BOSZ megvilágításában 1942-ben.] Fk. Melly József, Budapest, 1942; pp. 48-49. [Hungarian]

[26] Lehner K. Income limit of the mandatory health insurance. [A kötelező betegségbiztosítás censusa.] Közegészségügyi és orvosrendi kérdések a BOSZ megvilágításában 1942-ben. Fk. Melly József, Budapest, 1942; p. 51. [Hungarian]

[27] Fabinyi, G.: About the physicians' situation employed in public hospitals. [A közkórházi orvosok helyzetérôl.] Közegészségügyi és orvosrendi kérdések a BOSZ megvilágításában 1942-ben. Fk. Melly József, Budapest, 1942; pp. 63-74. [Hungarian]

[28] Hungarian Parliament, Act XX, 1949, Constitution of the Republic of Hungary. [Magyar Országgyúlés, 1949. évi XX. törvény, a Magyar Köztársaság Alkotmánya.] Available from: https://net. jogtar.hu/jogszabaly?docid=94900020.TV\&mahu=1 [accessed: July 31, 2018]. [Hungarian]

[29] Hungarian Parliament, Act LXXXIII, 1997, about the services provided by the mandatory health insurance. [Magyar Parlament, 1997. évi LXXXIII. törvény a kötelező egészségbiztosítás ellátásairól.] Available from: https://net.jogtar.hu/jogszabaly?docid=99700083.TV [accessed: July 31, 2018]. [Hungarian]

(Balázs Péter dr., Budapest, Nagyvárad tér 4., 1089 e-mail: balazs-peter@windowslive.com)

\section{"Male habet medicus, si nemo male habuerit." (Hogyha beteg nem akad, nem gazdagodik meg az orvos.)}

A cikk a Creative Commons Attribution 4.0 International License (https://creativecommons.org/licenses/by/4.0/) feltételei szerint publikált Open Access közlemény, melynek szellemében a cikk bármilyen médiumban szabadon felhasználható, megosztható és újraközölhetö, feltéve, hogy az eredeti szerző és a közlés helye, illetve a CC License linkje és az esetlegesen végrehajtott módositások feltüntetésre kerülnek. (SID_1) 